Aim of the study: Colorectal cancer (CRC) is one of the leading cause of death in European population. It progresses without any symptoms in the early stages or those clinical symptoms are very discrete. The aim of this study was a retrospective analysis of treatment outcomes in patients with colorectal cancer complicated with intestinal perforation.

Material and methods: A retrospective analysis of patients urgently operated upon in our Division of General Surgery, because of large intestine perforation, from February 1993 to February 2013 has been made. Results were compared with a group of patients undergoing the elective surgery for colorectal cancer in the same time and Division.

Results: Intestinal perforation occurred more often in males (6.52\% vs. $6.03 \%$ ), patients with mucous component in histopathological examination $(9.09 \%$ vs. $6.01 \%)$ and with clinicaly advanced CRC. Patients treated because of perforation had a five-fold higher 30 day mortality rate $(9.09 \%$ vs. $1.83 \%)$, however long-term survival did not differ significantly in both groups. After resectional surgery in 874 patients an intestinal anastomosis was made. Anastomotic leakage was present in $23(2.6 \%)$ patients. This complication occurred six-fold more frequently in a group of patients operated upon because of intestinal perforation $(12.20 \%$ vs. $2.16 \%$ ).

Conclusions: In patients with CRC complicated with perforation of the colon in a 30-day observation significantly higher rate of complications and mortality was shown, whereas there was no difference in distant survival rates.

Key words: colorectal cancer, complications, perforation, operation.

Contemp Oncol (Pozn) 2014; 18 (6): 414-418 DOI: $10.5114 /$ wo.2014.46362

\section{Colorectal cancer with intestinal perforation - a retrospective analysis of treatment outcomes}

\author{
Zbigniew Banaszkiewicz ${ }^{1}$, Łukasz Woda ${ }^{1}$, Krzysztof Tojek $^{1}$, \\ Paweł Jarmocik ${ }^{1}$, Arkadiusz Jawień ${ }^{2}$
}

${ }^{1}$ Division of General, Gastroenterological, Colorectal and Oncological Surgery, Departament of Vascular Surgery and Angiology, Collegium Medicum in Bydgoszcz, Nicolaus Copernicus University in Torun, Poland

2Department of Vascular Surgery and Angiology, Collegium Medicum in Bydgoszcz, Nicolaus Copernicus University in Torun, Poland

\section{Introduction}

In Europe cancer is the second leading cause of death. Responsible for this statistic, in nearly $45 \%$ of cases, are the four most frequent cancers: colorectal cancer (CRC), breast cancer in women, lung cancer, and prostate cancer [1].

Colorectal cancer progresses without any symptoms in the early stages, or those clinical symptoms are very discrete [2-4]. Only in about $15-30 \%$ of cases, people with CRC present symptoms of "acute abdomen" such as intestinal perforation, mechanical ileus, or bleeding from the gastrointestinal tract [5]. Those complications are most common in patients in the $6^{\text {th }}$ and $7^{\text {th }}$ decade of life, and they are connected with the worst prognosis [5-8]. Intestinal perforation may occur in the tumour site or in the cephalad direction as a complication of ileus, and it is more common in patients after radiotherapy or participating in chemotherapy [6, 9].

Intestinal perforations occur most commonly in CRC and in diverticular disease. Thye are seen less often in other diseases of the colon (ulcerative colitis, Lesniowski-Crohn disease), abdominal trauma therein iatrogenic (complications after surgery, after endoscopic examination, or after radiation therapy), colonic ischaemia, and necrosis [5, 10, 11].

In everyday practice, very few cases of CRC lead to perforation. Most commonly diagnosis of perforation is made intraoperatively and the confirmation is based on a histopathological examination made during the operation or performed after surgery. Diagnostics in patients with suspected intestinal perforation should be accurate and fast. Besides medical interview, physical examination and laboratory tests, imaging tests (USG, CT), and diagnostic laparoscopy are also used [12-14]. Qualification for operation should be made as quickly as possible to avoid presentation of shock, sepsis, or multiple organ dysfunction syndrome (MODS) $[12,15,16]$.

During the operation visual and palpable evaluation of intra-abdominal organs is made. The part of large intestine with the perforated tumour with necrotic tissue and infected fluid is removed. The specimen should be taken for microbiological examination. The removed intestine should be sent for pathomorphological evaluation and an adequate number of drains should be placed in the peritoneal cavity after lavage. The operation ends with restituting the intestine connection or more often with forming an intestinal stoma. The prevalence of complications after surgery in this group of patients is much higher than in patients with elective operation. Anastomotic leakage can be early and is a very dangerous complication. The prevalence of this complication is evaluated as $2.5-20 \%[17,18]$.

Diagnosis is based on clinical findings (leakage of pus/faeces through the wound or by drains, abscess, signs of peritonitis), laboratory and imag- 
ing tests (classical radiography with contrast medium, CT scan) [19]. Prognosis depends on the level of progression of peritonitis and on the stage of the tumour [2].

\section{Material and methods}

A retrospective analysis of patients urgently operated upon in our Division of General Surgery, because of large intestine perforation, from February 1993 to February 2013 was made. Results were compared with a group of patients undergoing the elective surgery for colorectal cancer in the same time and Division.

Patients with colorectal cancer operated upon because of reasons other than perforation were excluded from this comparison. All the patients were qualified for surgical treatment on the basis of clinical examination and imaging test results. Histopathological examination of samples was made in the Department of Pathomorphology in University Hospital No. 2 in Bydgoszcz.

Patients were divided in two groups with low (I and II degree of pathologico-clinical advancement) and high (III and IV degree) clinical advancement, according to International Union Against Cancer (UICC) TNM classification [31]. These two groups were further divided in two subgroups: a group of younger patients up to 64 years of age, and a group older than 64 years of age.

Only dominant postsurgical complication was taken for analysis if a patient had more than one complication. Statistical analysis was made with Statistica v.10 (StatSoft, Inc., USA) software. A log-linear analysis of qualitative variables affecting the occurrence of intestinal perforation was used. For the unrelated variables Pearson's Chi-squared test was used. The analysis of survival rate was made with Gehan-Wilcoxon test. The confidence level $p<0.05$ was considered statistically significant.

\section{Results}

A total of 1710 patients had been operated upon from February 1993 to February 2013 with colorectal cancer as a first diagnosis. Reliable medical history had been taken in 1378 (80.58\%) cases. In this group 229 (16.62\%) patients were admitted and treated with urgent operation because of CRC complications. The most numerous group of patients were patients with mechanical ileus 145 (10.52\%) and with intestinal perforation 77 (5.58\%). A group of 77 patients operated upon because of perforation was compared with 1149 patients who were undergoing elective surgery for CRC at the same time.

From a performed log-linear analysis the conclusion was made that the main factors responsible for intestinal perforation are tumour localisation and occurrence of a mucinous component in histopathological examination. No influence was demonstrated for age, sex, comorbidities, or clinical advancement of CRC.

Intestinal perforation occurred more often in males (6.52\% vs. 6.03\%), patients with a mucinous component in histopathological examination (9.09\% vs. 6.01\%) and with clinically advanced CRC (Table 1). The difference was not statistically significant.

In the analysed group there were 711 patients over 64 years of age. Clinical advancement of CRC as well as intestinal perforation complication showed almost the same incidence as in younger patients (6.47\% vs. 6.02\%) (Table 1 ).

Cancer (tumour) was most frequently localised in the rectum 500/1226 (40.78\%), and this localisation was seldom the cause of perforation. Intestinal perforation occurred two-fold more frequently with colonic localisation, regardless of whether it was on the right or left side of colon. These differences were statistically significant.

In a group of 241 (19.66\%) patients only palliative operations were performed, of which, in a group of 151 (12.32\%) patients, operations were unresectional. There were twofold fewer palliative and unresectional operations in a group of patients operated on because of intestinal perforation (Table 3). Differences with the possibility of resection were statistically significant.

During 30-day observation 28 (2.28\%) patients died after surgical treatment. The cause of death in 12 patients

Table 1. Results of comparison in a group of patients with colorectal cancer without complications and with additional intestinal perforation

\begin{tabular}{|c|c|c|c|c|}
\hline & & $\begin{array}{l}\text { Colorectal cancer without } \\
\text { complications }\end{array}$ & $\begin{array}{l}\text { Colorectal cancer with intestinal } \\
\text { perforation }\end{array}$ & $p$ \\
\hline Sex & $\begin{array}{l}\text { females } \\
\text { males }\end{array}$ & $\begin{array}{l}561(93.97 \%) \\
588(93.48 \%)\end{array}$ & $\begin{array}{l}36(6.03 \%) \\
41(6.52 \%)\end{array}$ & NS \\
\hline Age (years) & $\begin{array}{l}<65 \\
>64\end{array}$ & $\begin{array}{l}484(93.98 \%) \\
665(93.53 \%)\end{array}$ & $\begin{array}{l}31(6.02 \%) \\
46(6.47 \%)\end{array}$ & NS \\
\hline $\begin{array}{l}\text { Clinical } \\
\text { advancement } \\
\text { of CRC }\end{array}$ & $\begin{array}{l}\text { low } \\
\text { high }\end{array}$ & $\begin{array}{l}623(93.83 \%) \\
526(93.59 \%)\end{array}$ & $\begin{array}{l}41(6.17 \%) \\
36(6.41 \%)\end{array}$ & NS \\
\hline Comorbidities & $\begin{array}{l}\text { cardiovascular disease } \\
\text { pulmonary disease } \\
\text { diabetes type } 2 \\
\text { renal insufficiency }\end{array}$ & $\begin{array}{c}475(36.51 \%) \\
39(3.00 \%) \\
205(15.76 \%) \\
46(3.54 \%)\end{array}$ & $\begin{array}{c}22(28.57 \%) \\
4(5.19 \%) \\
16(29.78 \%) \\
3(3.90 \%)\end{array}$ & $\begin{array}{l}\text { NS } \\
\text { NS } \\
\text { NS } \\
\text { NS }\end{array}$ \\
\hline $\begin{array}{l}\text { Tumor } \\
\text { localization }\end{array}$ & $\begin{array}{l}\text { colon } \\
\text { rectum } \\
\text { right side of colon } \\
\text { left side of colon }\end{array}$ & $\begin{array}{l}670(91.78 \%) \\
479(96.57 \%) \\
348(92.06 \%) \\
322(91.48 \%)\end{array}$ & $\begin{array}{l}60(8.22 \%) \\
17(3.43 \%) \\
30(7.94 \%) \\
30(8.52 \%)\end{array}$ & $\begin{array}{l}0.0007 \\
\text { NS }\end{array}$ \\
\hline $\begin{array}{l}\text { Mucinous } \\
\text { component }\end{array}$ & $\begin{array}{l}\text { present } \\
\text { absent }\end{array}$ & $\begin{array}{c}69(6.01 \%) \\
1080(93.99 \%)\end{array}$ & $\begin{array}{c}7(9.09 \%) \\
70(90.91 \%)\end{array}$ & NS \\
\hline
\end{tabular}


Table 2. Complications after surgical treatment

\begin{tabular}{lcc} 
Complications & Number & $\%$ \\
Wound healing & 55 & 4.59 \\
Pulmonary & 10 & 0.83 \\
Cardiological & 4 & 0.33 \\
Urinary & 9 & 0.75 \\
Intestinal anastomosis & 17 & 1.42 \\
insufficiency & 15 & 1.25 \\
Ileus & 1088 & 90.83 \\
Without complications & 1198 & 100.00 \\
\hline Total & & \\
\hline
\end{tabular}

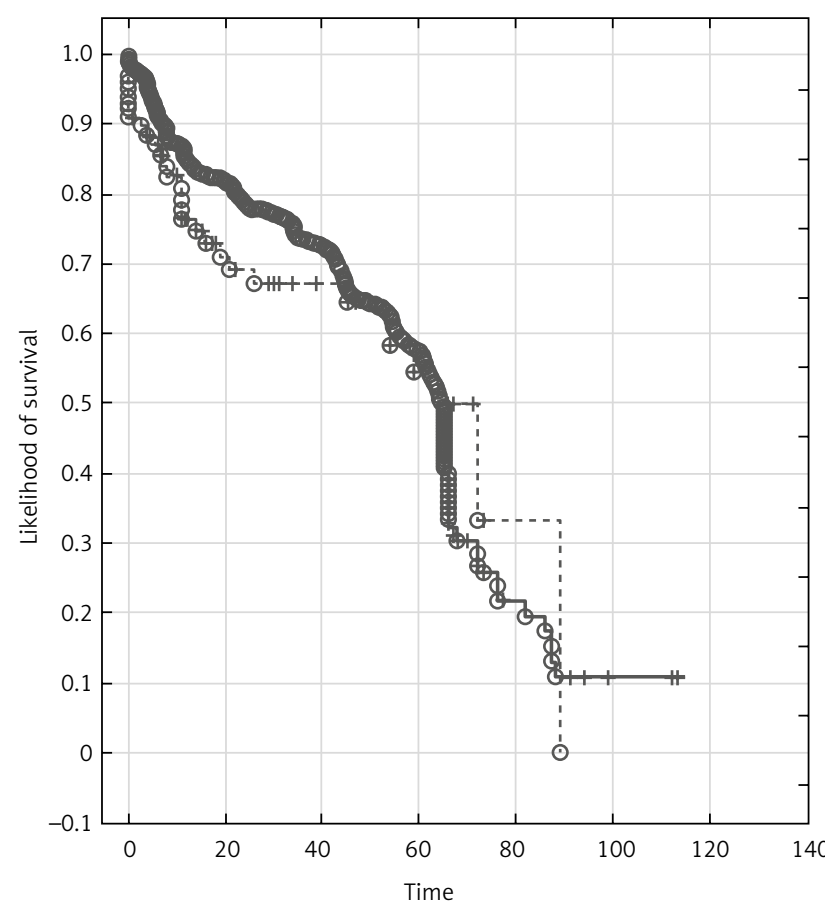

— patients without complications -.-p patients with intestinal perforation

$$
\text { O Complete + cutt-off }
$$

Gehan-Wilcoxon test (CA02 $\mathrm{w}$ ca13PERF) WW $=6072,0$, Sum $=2711 \mathrm{E} 5$, $\mathrm{Val}=1597 \mathrm{E} 4$

Test statisctics 1.519396, $p=0.12866$

Fig. 1. Patients survival dependent on operation performed because of intestinal perforation was multiple organ dysfunction syndrome induced by faecal peritonitis that occurred shortly after operation. The rest of the 16 patients had post-operative complications that were the cause of death.

Six patients died because of complications related to insufficient intestinal anastomosis after surgery, and four patients died because of complications related to intestinal obstruction. In two patients the cause of death was associated with pulmonary complications, and in four patients it was associated with cardiological complications. Of the other 1198 patients 110 (9.17\%) had complications in 30-day observation. The most frequent complications were associated with wound healing $(55 / 4.59 \%$ - Table 2$)$. Post-operative complications most often occurred in patients who underwent urgent operation because of intestinal perforation ( $21.43 \%$ vs. $8.42 \%$ - Table 3 ).

After resectional surgery, in 874 patients an intestinal anastomosis was made. Anastomotic leakage was present in $23(2.6 \%)$ patients. In this group six (26\%) patients died. This complication occurred six-fold more frequently in a group of patients operated upon because of intestinal perforation (12.20\% vs. 2.16\%) (Table 3).

In the examined group postoperative mortality (30 days) was 2.28\% (28/1226). Patients treated because of perforation had a five-fold higher 30-day mortality rate (9.09\% vs. $1.83 \%)$, and this difference was statistically significant. However, long-term survival did not differ significantly in both groups (Table 3, Fig. 1).

\section{Discussion}

Surgical treatment of CRC is essential. In over $80 \%$ of patients the treatment is elective after complex diagnosis and preparation. In some cases where CRC is recognised an emergency surgery (service) must be performed immediately. This can even happen during an exploratory operation. Those are the patients with acute abdomen, who require immediate surgical intervention, so the preparation for this procedure is limited. This mostly refers to patients with an advanced stage of the disease. In the analysed group among patients with an advanced stage of CRC, the number of patients operated upon because of perforation was slightly higher in comparison with patients who underwent elective surgery (6.41\% vs. $6.17 \%)$, but this difference was not statistically significant. However, in other recently published studies, it was shown that the stage

Table 3. Results of comparative analysis between patients with colorectal cancer without complications and with intestinal perforation

\begin{tabular}{|c|c|c|c|c|}
\hline & & $\begin{array}{l}\text { Colorectal cancer without } \\
\text { complications }\end{array}$ & $\begin{array}{l}\text { Colorectal cancer with intestinal } \\
\text { perforation }\end{array}$ & $p$ \\
\hline \multirow[t]{4}{*}{ Surgical treatment } & \multirow{4}{*}{$\begin{array}{l}\text { resectable } \\
\text { unresectable } \\
\text { radical } \\
\text { nonradical }\end{array}$} & \multirow{4}{*}{$\begin{array}{c}1002(87.21 \%) \\
147(12.79 \%) \\
908(79.03 \%) \\
241(20.97 \%)\end{array}$} & \multirow{4}{*}{$\begin{array}{c}73(94.81 \%) \\
4(5.19 \%) \\
68(88.31 \%) \\
9(11.69 \%)\end{array}$} & 0.049 \\
\hline & & & & \multirow{3}{*}{ NS } \\
\hline & & & & \\
\hline & & & & \\
\hline \multirow{2}{*}{$\begin{array}{l}\text { Post-operational } \\
\text { complications }\end{array}$} & present & 95 (8.42\%) & $15(21.43 \%)$ & \multirow[t]{2}{*}{0.00026} \\
\hline & absent & 1033 (91.58\%) & $55(78.57 \%)$ & \\
\hline \multirow[t]{2}{*}{ Anastomotic leakage } & present & $18(2.16 \%)$ & $5(12.20 \%)$ & \multirow[t]{2}{*}{0.00009} \\
\hline & absent & 815 (97.84\%) & $36(87.80 \%)$ & \\
\hline \multirow[t]{2}{*}{ Death } & yes & 21 (1.83\%) & 7 (9.09\%) & \multirow[t]{2}{*}{0.00004} \\
\hline & no & $1128(98.17 \%)$ & $70(90.91 \%)$ & \\
\hline
\end{tabular}


of cancer advancement had an influence on the type of procedure. Patients with stage IV cancer more frequently underwent urgent operation, which was statistically significant [20-23].

In his work Chiarugi et al. performed a retrospective analysis of 499 patients who underwent the operation, and concluded that $85(17 \%)$ patients were operated upon because of intestinal ileus and $30(6 \%)$ patients because of intestinal perforation [20]. In the observed group of 1378 patients, the number of patients who underwent urgent surgery was much lower (16.62\%). The largest group were patients with intestinal ileus - 145 (10.52\%) and with intestinal perforation 77 (5.58\%).

Perforation most frequently occurred in patients with the cancer tumour localised in the left part of the colon (8.52\%), and least frequently when it was localised in the rectum (3.43\%). Different data about localisation of the tumour causing the perforation can be found in the literature. Fujisaki et al. found the highest number of tumours (77\%) in the sigmoid colon and rectum; however, Ghazi et al. noted no difference in the incidence of this complication based on the location of the tumour $[22,24]$.

Despite the generally more difficult conditions of operation and often greater degree of CRC advancement, the resection rate among patients who underwent urgent operation remains high (60-81\%). This draws attention to the lower number of lymph nodes in the pathomorphological examination [24-26]. In our own analysed material $88 \%$ of patients underwent resectional operation. They were performed significantly more often in patients with CRC with bowel perforation ( $p=0.049494)$, despite no difference in tumour stage.

The reasons for this state can be traced to a difficult diagnostic-clinical situation encountered by the surgeon during the emergency duty. Often the operator decides to make resection surgery despite the lack of accurate imaging studies and the lack of belief in the radical surgery, so these treatments are burdened with much higher morbidity and mortality rates. Radical surgery assessed on the basis of pathological examination in our material is also slightly higher compared to elective procedures (88.31\% vs. $79.03 \%$ ), but these differences were not statistically significant.

After surgery due to intestinal perforation in the course of CRC, more postoperative complications were observed (complications occurred in every fifth patient in the 30-day observation). Compared to patients with CRC undergoing elective surgery, they occurred significantly more often (21.43\% vs. $8.42 \%, p=0.000256)$.

In the studied group of patients, clinically symptomatic anastomotic leakage after surgery occurred in 23 (2.6\%) patients and significantly more often in patients undergoing surgery due to intestinal perforation (12.20 vs. 2.16\%).

In the available literature, the mortality rate in patients with CRC, operated upon due to perforated intestine, ranged from $6 \%$ to $15 \%$ [24-27]. Compared to patients undergoing elective surgery it was significantly higher [25, 26]. In contrast, the survival rate was different. In studies by Zielinski et al. and Abdelrazeqa et al. the mortality rate was at the same level. In studies by Bass et al., McArdle et al., and Metcalfe et al. a significantly lower distant survival rate was observed [21, 25, 28-30]. In our group of patients, in the 30-day observation, 28 (2.28\%) patients died. The mortality rate was significantly higher (9.09\% vs. $1.83 \%$ ) in patients undergoing surgery due to perforation. In contrast, long-term survival in both groups of patients undergoing surgery was not significantly different $(p=0.12866)$.

In conclusions, colorectal cancer complication as an intestinal perforation was significantly more frequent in patients with tumours localised in the rectum.

In patients with CRC complicated with perforation of the colon, significantly more resectional operations were performed, in the absence of differences in the stage of cancer.

In 30-day observation, patients with CRC complicated with perforation of the colon showed a significantly higher rate of complications and mortality; however, there were no differences in long-term survival rates.

\section{The authors declare no conflict of interest.}

\section{References}

1. Richard F. Mould. Statystyka zachorowań na nowotwory ze szczególnym uwzględnieniem raka prostaty, okrężnicy i odbytnicy, płuca oraz piersi i szyjki macicy. Nowotwory 2008; 58: 213-20.

2. Błachut K, Błoński W, Paradowski L. Zaparcie. Przyczyny, diagnostyka, leczenie. Gastroenterol Pol 2004; 11: 171-80.

3. Langenbach MR, Schmidt J, Neumann J, Zirngibl H. Delay in treatment of colorectal cancer: multifactorial problem World J Surg 2003; 27: 304-8.

4. Banaszkiewicz Z, Tojek K, Jarmocik P, Frasz J, Jawień A. Kliniczne objawy raka jelita grubego - badanie retrospektywne. Współcz Onkol 2009; 13: 34-40.

5. Wong SK, Jalaludin BB, Morgan MJ, Berthelsen AS, Morgan A, Gatenby AH, Fulham SB. Tumor pathology and long-term survival in emergency colorectal cancer. Dis Colon Rectum 2008; 51: 223 30.

6. Bielecki K, Kamiński P, Klukowski M. Large bowel perforation: Morbidity and mortality. Tech Coloproctol 2002; 6: 177-82.

7. Pavlidis TE, Marakis G, Ballas K, Rafailidis S, Psarras K, Pissas D, Papanicolaou K, Sakantamis A. Safety of bowel resection for colorectal surgical emergency in the elderly. Colorectal Dis 2006; 8: 657-62.

8. Weigelt JA. Empiric treatment options in the management of complicated intra-abdominal infections. Cleveland Clin J Med 2007; 74 Suppl 4: 29-37.

9. McGillicuddy EA, Schuster KM, Davis KA, Longo WE. Factors predicting morbidity and mortality in emergency colorectal procedures in elderly patients. Arch Surg 2009; 144: 1157-62.

10. Vermeulen J, Lange JF. Treatment of perforated diverticulitis with generalized peritonitis: past, present and future. World J Surg 2010; 34: 587-93.

11. McGillicuddy EA, Schuster KM, Davis KA, Longo WE. Factors predicting morbidity and mortality in emergency colorectal procedures in elderly patients. Arch Surg 2009; 144: 1157-62.

12. Moller MH, Adamsen S, Wojdemann M, Moller M. Perforated peptic ulcer: how to improve outcome? Scand J Gastroenterol 2009; 44: 15-22.

13. Laal M, Mardanloo A. Acute abdomen; pre and post-laparoto-my diagnosis. Int J Coll Res Intern Med Public Health 2009; 1: 157-65.

14. Banz VM, Butt MU, Zimmermann H, Jeger V, Exadaktylos AK. Free abdominal flu-id without obvious solid organ injury upon CT imaging: an actual problem or simply over-diagnosing? J Trauma Manag Outcomes 2009; 3: 10-7. 
15. Khamphommala L, Parc Y, Bennis M, Ollivier JM, Dehni N, Tiret E, Parc R. Results of an aggressive surgical app roach in the management of postoperative peritonitis. ANZ I Surg 2008; 78: 881-8.

16. Okubo R, Yajima K, Sakai Y, Kido T, Hirano K, Musha N, Tsubono T, Hatakeyama K. Short- and long-term outcomes of surgery for diffuse peritonitis in patients 80 years of age and older. Surg Today 2008; 38: 413-9.

17. Ploeg RJ, Sijbrand Hofker H, Wiggers T, Havenga K. Late anastomotic leakage in colorectal surgery: a significant problem. Colorectal Dis 2013; 15: e271-5.

18. Vennix S, Abegg R, Bakker OJ, van den Boezem PB, Brokelman WJ, Sietses C, Bosscha K, Lips DJ, Prins HA. Surgical Re-interventions Following Colorectal Surgery: Open Versus Laparoscopic Management of Anastomotic Leakage. J Laparoendosc Adv Surg Tech A 2013; 23: 739-44.

19. Bruce J, Krukowski ZH, Al-Khairy G, Russell EM, Park KG. Systematic review of the definition and measurement of anastomotic leak after gastrointestinal surgery. Br J Surg 2001; 88: 1157-68.

20. Chiarugi M, Galatioto C, Panicucci S, Scassa F, Zocco G, Seccia M. Oncologic colon cancer resection in emergency: are we doing enough? Surg Oncol 2007; 16 Suppl 1: S73-7.

21. Abdelrazeq AS, Scott N, Thorn C, Verbeke CS, Ambrose NS, Botterill ID, Jayne DG. The impact of spontaneous tumour perforation on outcome following colon cancer surgery. Colorectal Dis 2008; 10: $775-80$

22. Ghazi S, Berg E, Lindblom A, Lindforss U. Clinicopathological analysis of colorectal cancer: a comparison between emergency and elective surgical cases. World J Surg Oncol 2013; 11: 133.

23. Sawayama H, Tomiyasu S, Kanemitsu K, Matsumoto T, Tanaka H, Baba H. Colonic perforation due to colorectal cancer: predicting postoperative organ failure with a preoperative scoring system and selecting the optimal surgical method based on the prognosis. Surg Today 2012; 42: 1082-7.

24. Fujisaki S, Takashina M, Sakurai K, Tomita R, Takayama T. Perforation associated with colorectal cancer. Gan To Kagaku Ryoho 2012; 39: 1908-10.

25. Zielinski MD, Merchea A, Heller SF, You YN. Emergency manage ment of perforated colon cancers: how aggressive should we be? J Gastrointest Surg 2011; 15: 2232-8.

26. Khan S, Pawlak SE, Eggenberger JC, Lee CS, Szilagy EJ, Margolin DA. Acute colonic perforation associated with colorectal cancer. Am Surg 2001; 67: 261-4.

27. Chen HS, Sheen-Chen SM. Obstruction and perforation in colorec tal adenocarcinoma: an analysis of prognosis and current trends. Surgery 2000; 127: 370-6.

28. Bass G, Fleming C, Conneely J, Martin Z, Mealy K. Emergency first presentation of colorectal cancer predicts significantly poorer outcomes: a review of 356 consecutive Irish patients. Dis Colon Rectum 2009; 52: 678-84.

29. McArdle CS, Hole DJ. Emergency presentation of colorectal cancer is associated with poor 5-year survival. Br J Surg 2004; 91: 605-9.

30. Metcalfe MS, Norwood MG, Miller AS, Hemingway D: Unreasonable expectations in emergency colorectal cancer surgery. Colorectal Dis 2005; 7 : 275-8.

31. International Union Against Cancer (UICC) TNM Classification of Malignant Tumors. Sobin LH, Gospodarowicz MK, Wittekind Ch (eds.). $7^{\text {th }}$ ed. Wiley-Blackwell, Oxford 2009

\section{Address for correspondence}

\section{Zbigniew Banaszkiewicz}

Division of General, Gastroenterological,

Colorectal and Oncological Surgery

Departament of Vascular Surgery and Angiology

Collegium Medicum in Bydgoszcz

Nicolaus Copernicus University in Torun, Poland

e-mail: banasz@cm.umk.pl

Submitted: 3.08 .2014

Accepted: $\quad 5.09 .2014$ 